\title{
Pengembangan Lembar Kerja Peserta Didik (LKPD) Sosiologi Kelas X SMA Berbasis Discovery Learning
}

\author{
Dian Nurhayati ${ }^{1}$, Ike Sylvia ${ }^{2}$ \\ ${ }^{1,2}$ Universitas Negeri Padang \\ Email: diannurhayati923@gmail.com., ikesylvia@fis.unp.ac.id
}

\begin{abstract}
Abstrak
Penelitian ini dilatar belakangi oleh belum tercapainya penguasaan materi pada peserta didik dan kurangnya sumber belajar yang tersedia di sekolah. Metode yang digunakan oleh gurunya juga masih berupa metode ceramah (techer centered) yang hanya berpusat pada guru, sedangkan kurikulum 2013 menuntut peerta didik untuk aktif dalam pembelajaran dan membiasakan peserta didik peserta didika didik untuk terbiasa membangun konsep dalam proses belajar. Penelitian bertujuan untuk mengembangkan LKPD Sosiologi berbasis Discovery Learning pada materi perilaku Menyimpang untuk mengetahui validitas, praktikalitas dan efektifitasnya. Penelitian ini berjenis R\&D, LKPD ini dirancang mengikuti model pengembangan $4 \mathrm{D}$ dan diujicobakan pada peserta didik kelas X di SMA Negeri 2 Payakumbuh. Teknik pengumpulan data melalui observasi, angket dan soal. Sampel pada penelitian ini adalah peserta didik kelas $\mathrm{X}$ IPS 1 berjumlah 38 orang. Data dianalisis menggunakan rumus persentase dan Uji T untuk melihat perbedaan skor pretest dan posttest. Penelitian ini dianalisis dengan teori konstruktivistik yang dikemukakan oleh Piaget. Temuan penelitian LKPD yang dikembangkan valid, praktis dan efektif.
\end{abstract}

Kata kunci: Lembar Kerja Peserta Didik, Penguasaan Materi, Pembelajaran Sosiologi

\section{Abstract}

This research is motivated by the lack of mastery of the material for students and the lack of learning resources available in schools. The method used by the teacher is also still in the form of a lecture method (techer centered) which is only teacher-centered, while the 2013 curriculum requires students to be active in learning and familiarize students to get used to building concepts in the learning process. This study aims to develop Discovery Learning-based Sociology worksheets on Deviant behavior material to determine its validity, practicality and effectiveness. This research is an $R \& D$ type, this LKPD is designed to follow the $4 D$ development model and tested on class $X$ students at SMA Negeri 2 Payakumbuh. Data collection techniques through observation, questionnaires and questions. The sample in this study were 38 students of class X IPS 1 totaling 38 people. The data were analyzed using the percentage formula and T-test to see the difference in the pretest and posttest scores. This research was analyzed by constructivist theory proposed by Piaget. The findings of the developed LKPD research are valid, practical and effective.

Keywords: Material Mastery, Sociology Learning, Student Worksheet

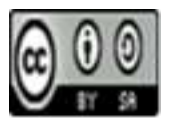




\section{Pendahuluan}

Abad ke-21 dikenal dengan masa pengetahuan. Pada era ini pendidikan hendaknya mampu menjawab atas berbagai permasalahan yang ada. Menurut Greenstein (2012) dalam (Dwi et al., 2019) menyatakan bahwa peserta didik yang hidup pada abad 21 harus menguasai keilmuan, berketerampilan metakognitif, mampu berfikir kritis dan kreatif, serta bisa berkomunikasi atau berkolaborasi yang efektif. Namun keadaan yang terjadi peserta didik didik saat ini belum menguasai butir pengetahuan yang dibutuhkan pada abad 21 ini. Hal tersebut karena banyak pembelajaran masih terfokus pada guru (teacher centered), apalagi dengan keadaan pandemi Covid19 yang mengharuskan pembelajaran jarak jauh, guru hanya menjelaskan materi yang diambil dari buku cetak dan memindahkannya ke dalam aplikasi seperti whatsapp, google meet, google clasroom, dan lain lain yang sama sekali tidak mengikuti sintak model pembelajaran yang mampu melibatkan keaktifan peseta didik, kegiatan untuk mengasah keterampilan, pemikiran yang kritis dan kreatif serta tidak adanya komunikasi atau kolaborasi dalam kelompok belajar.

Kurikulum nasional yang digunakan dalam pembelajaran saat ini dikenal dengan nama kurikulum 2013, telah memberikan arahan jelas bahwa peserta didik wajib memiliki pengalaman belajar dengan memberikan penekanan perlunya penyelidikan ilmiah (inquiry) agar peserta didik mampu melakukan sinkronisasi antara materi yang dipelajari dan realita yang ada disekitarnya (authentic), dengan harapan peserta didik mampu mengkonstruksi konsep serta melatih kemampuan metakognitifnya. (Sylvia, Anwar, \& Khairani, 2019). Kurikulum 2013 bertujuan untuk mempersiapkan warga negara Indonesia agar memiliki kemampuan hidup sebagai pribadi yang beriman, kreatif, inovatif, produktif serta mampu berkontribusi pada kehidupan bermasyarakat, berbangsa, bernegara, dan peradaban dunia. Kurikulum 2013 memiliki tuntutan pembelajaran yang berbasis pada peserta didik, sedangkan guru hanya sebagai fasilitator yang mengakomodasi berkembangnya kemampuan peserta didik.

Pendidikan yang berkualitas melibatkan peserta didik untuk aktif belajar, untuk mencapai kualitas dalam kegiatan pembelajaran perlu menggunakan prinsip: (1) pembelajaran berpusat pada peserta didik; (2) mengembangkan kreativitas peserta didik; (3) menciptakan kondisi pembelajaran menyenangkan; (4) mempunyai nilai, etika, estetika, logika dan kinestetika; (5) penerapan berbagai strategi dan metode pembelajaran M. Hosnan dalam (Ermi Netti, n.d.) Kurikulum 2013 mempunyai landasan filosofi yang salah satunya berbunyi "Peserta didik adalah pewaris budaya bangsa yang kreatif", oleh karena itu belajar merupakan proses peserta didik mengalami perubahan melalui latihan dan pengalaman. Tercapainya proses belajar dapat dilihat perubahan kompetensi peserta didik. Kompetensi belajar memiliki faktor-faktor yaitu : (1) Peran guru; (2) peran peserta didik; (3) peran sumber belajar. (Frastiyanti, 2018)

Keaktifan peserta didik dapat diwujudkan baik keaktifan fisik maupun keaktifan mental. Interaksi yang baik antara guru dan peserta didik sangat diperlukan agar proses pembelajaran dapat berlangsung efektif. Interaksi belajar mengajar dapat dilakukan dengan mengaktifkan peserta didik menggunakan teknik tanya jawab atau dialog yang interaktif dalam proses pembelajaran, interaksi belajar-mengajar memiliki tujuan, ada suatu prosedur (jalannya interaksi) yang terencana, interaksi belajar mengajar ditandai dengan suatu penggarapan materi yang khusus, ditandai dengan adanya aktivitas peserta didik, dalam interaksi belajar mengajar guru berperan sebagai pembimbing, didalam interaksi belajar mengajar membutuhkan disiplin, dan memiliki batas waktu. (Nur Inah, 2015). Keaktifan peserta didik dalam proses pembelajaran merupakan salah satu hal penting dalam pembelajaran dan memengaruhi keberhasilan peserta didik dalam belajar. Supriyono Koes H dalam (Frastiyanti, 2017) menyatakan bahwa satu kata kunci untuk pembelajaran adalah pembelajaran harus melibatkan peserta didik secara aktif untuk berinteraksi dengan objek konkrit. Keterlibatan peserta didik tersebut diharapkan dapat mengembangkan kreativitas yang melibatkan imajinasi dan penemuan dengan mengembangkan pemikiran orisinil dan rasa ingin tahu. Dengan demikian, peserta didik akan lebih tertarik untuk belajar jika peserta didik dilibatkan secara aktif dalam pembelajaran. 
Adanya interaksi multi arah secara langsung akan membuat pembelajaran lebih bermakna. Keaktifan peserta didik dalam proses pembelajaran merupakan salah satu hal penting dalam pembelajaran dan memengaruhi keberhasilan peserta didik dalam belajar. Keterlibatan peserta didik tersebut diharapkan dapat mengembangkan kreativitas yang melibatkan imajinasi dan penemuan dengan mengembangkan pemikiran orisinil dan rasa ingin tahu. Menurut Purwaningrum (Purwaningrum, 2016) kreatif merupakan pemikiran yang bersifat asli, reflektif, dan menghasilkan suatu produk yang kompleks. Dapat dipahami bahwa suatu pembelajaran yang baik apabila keaktifan peserta didik aktif dalam jasmani maupun mentalnya semakin tinggi. Sebaliknya meskipun seseorang dikatakan belajar, namun jika keaktifan jasmani dan mentalnya rendah berarti kegiatan belajar tersebut tidak secara nyata memahami bahwa dirinya melakukan kegiatan belajar. (Apriyada, 2017).

Salah satu sumber belajar yang digunakan dalam kurikulum 2013 adalah lembar kerja peserta didik (LKPD), oleh karena itu dibutuhkan adanya perangkat pembelajaran yang aktif mengembangkan peserta didik. LKPD merupakan sarana untuk membantu dan mempermudah dalam kegiatan belajar mengajar sehingga terbentuk interaksi peserta didik dalam (Umbaryanti, 2013)

Media pembelajaran yang digunakan sebagai sarana kegiatan peserta didik masih berupa LKPD versi cetak. Menurut Istikharah (Istikharah, 2017) LKPD merupakan salah satu bentuk sumber belajar yang berbentuk media cetak. Dalam implementasi Kurikulum 2013 bahan ajar berupa LKPD diharapkan dapat menjadi salah satu alternatif dalam melengkapi bahan ajar pada pembelajaran Kurikulum 2013.

Hasil observasi yang dilakukan pada pembelajaran sosiologi kelas $\mathrm{X}$ di SMA $\mathrm{N} 2$ Payakumbuh diperoleh informasi bahwa proses belajar mengajar sosiologi selama pandemi hampir semua informasi berasal dari guru dan peserta didik berperan sebagai penerima informasi. Disamping itu juga diperoleh data bahwa nilai hasil belajar sosiologi peserta didik kelas X masih rendah atau di bawah KKM (kriteria ketuntasan minimal) yang ditetapkan. Nilai rata-rata ulangan harian peserta didik berada pada rentang 46 - 56 dengan KKM 75 pada materi. Karena dalam proses pembelajaran dan media pembelajaran yang kurang bervariasi, maka peserta didik kurang terangsang dan merespon materi yang disampaikan sehingga peserta didik kurang terampil dan aktif dalam proses pembelajaran. Selain itu juga pembelajaran untuk peserta didik yang sama sekali belum pernah tatap muka kemudian harus belajar daring membuat mereka membutuhkan sumber belajar lain yang menjadi pedoman langkah-langkah pembelajaran yang sesuai dengan rencana pelaksanaan pembelajaran yang telah dibuat oleh guru. Berikut adalah nilai UH peserta didik pada KD 3.1. Materi Interaksi Sosial.

Tabel 1. Penilaian KD 3.1. Materi Interaksi Sosial di SMA N 2 Payakumbuh

\begin{tabular}{lcccc} 
No & Kelas & $\begin{array}{c}\text { Jumlah Peserta } \\
\text { didik }\end{array}$ & $\begin{array}{c}\text { Rata-rata Skor } \\
\text { Pengetahuan }\end{array}$ & $\begin{array}{c}\text { Rata-rata Skor } \\
\text { Keterampilan }\end{array}$ \\
\hline 1 & X IPS 1 & 26 & 46,34 & 75,38 \\
\hline 2 & X IPS 2 & 25 & 56 & 68 \\
\hline 3 & X IPS 3 & 26 & 46,34 & 75,57 \\
\hline
\end{tabular}

Data di atas memperlihatkan hasil yang berada di bawah KKM. Berdasarkan hasil wawancara dengan guru mata pelajaran sosiologi kelas X SMA N 2 Payakumbuh pada tanggal 20 Oktober 2020, menyebutkan terdapat dua permasalahan pada pembelajaran sosiologi. Permasalahan tersebut yaitu kurangnya sumber belajar yang digunakan peseta didik. Menurut Hamalik (Wijayanti \& Hindarto, 2012) kesulitan belajar adalah hal-hal yang bisa mengakibatkan kegagalan atau menjadi gangguan yang bisa menghambat kemajuan belajar. Pada pembelajaran

Jurnal Sikola: Jurnal Kajian Pendidikan dan Pembelajaran Vol. 3, No. 1, Th. 2021 
sosiologi khususnya materi Interaksi Sosial, peserta didik kurang memahami materi dan masih bergantung pada bimbingan guru sehingga banyak peserta didik yang kurang aktif dalam mencari dan mengembangkan pengetahuannya sendiri. Guru yang selalu menjadi sumber informasi dalam pembelajaran dan peserta didik yang bekerja hanya berpatokan pada contoh yang diberikan guru mengindikasikan sikap kritis yang rendah. Kemampuan peserta didik dalam mengaitkan informasi yang sudah ada dengan informasi baru ketika menyelesaikan masalah tidak cukup baik.

Kemampuan peserta didik menyelesaikan masalah dengan mengaitkan melalui informasi yang sudah ada dengan informasi baru belum cukup baik. Proses pembelajaran teacher centered menyebabkan peserta didik menjadi kurang aktif dalam pembelajaran dan memiliki keterbatasan dalam mengeksplorasi materi sehingga daya analisis dan reflektif masih kurang terlatih. Kelemahan pendekatan teacher centered, yaitu peserta didik cenderung pasif sehingga kurang cocok untuk penguasaan materi, pembentukan keterampilan dan sikap. Peserta didik hanya mendengarkan penjelasan guru dan kurang mendapat kesempatan mengekspresikan pemikirannya melalui lisan maupun tulisan. Upaya untuk mengatasi masalah tersebut salah satunya adalah dengan menyelenggarakan pembelajaran sosiologi yang lebih kontekstual menekankan aktivitas, keterampilan dan pencarian aktif.

Salah satu cara penyelenggarakn pembelajaran yang kontekstual adalah dengan memberikan tugas yang sesuai dengan langkah-langkah pembelajaran yang dirancang oleh guru melalui LKPD yang bersifat kontekstual dan mendukung kegiatan peserta didik dalam menemukan konsep melalui penyelidikan. LKPD dibutuhkan untuk perbaikan kegiatan pembelajaran yang berlangsung secara monoton yaitu berkutat dengan teori sehingga tidak terbiasa belajar melalui penemuan atau percobaan. Sumber belajar berupa LKPD merupakan lembaran berisi kegiatan peserta didik untuk melakukan kegiatan pembelajaran menggunakan objek nyata untuk dipelajari dan kemudian dikumpulkan menjadi sebuah buku. Prastowo dalam (Syamsu, 2020) LKPD berperan sebagai sumber belajar untuk membantu mengarahkan dan juga memudahkan peserta didik melakukan aktivitas pembelajaran, karena berisi materi, rangkuman dan petunjuk langkah-langkah melaksanakan tugas berupa teori maupun praktikum yang harus dikerjakan peserta didik, serta mengacu pada kompetensi dasar yang ditetapkan. Dengan demikian peserta didik akan terlibat didalam proses pembelajaran karena didalam lembar kerja peserta didik akan melibatkan peserta didik dalam menemukan konsep, peserta didik menjadi aktif belajar dan bisa mengeksplorasi materi sehingga daya analisis dan penguasaan materi bisa didapatkan oleh peserta didik.

Berdasarkan uraian di atas, untuk meningkatkan penguasaan materi peserta didik, maka perlu adanya pengembangan sumber belajar berupa LKPD. Penggunaan sumber belajar seperti LKPD menjadi salah satu alternatif untuk meningkatkan penguasaan materi peserta didik (Nurliawaty, Mujasam, Yusuf, \& Widyaningsih, 2017). Sumber belajar berupa LKPD merupakan lembaran berisi kegiatan peserta didik untuk melakukan kegiatan pembelajaran menggunakan objek nyata untuk dipelajari dan kemudian dikumpulkan menjadi sebuah buku. LKPD atau dalam kata lain worksheet merupakan suatu media pembelajaran yang dapat digunakan untuk mendukung proses belajar (Sari \& Lepiyanto, 2016). Sementara LKPD yang digunakan di SMA N 2 Payakumbuh masih versi cetak yang isinya hanya berisi latihan soal saja tanpa adanya kegiatan yang melibatkan peserta didik. Peserta didik belum memperoleh pembelajaran bermakna dari proses observasi di luar sekolah, kemudian menemukan konsep tersebut setelah mengaitkannya dengan materi yang dipelajari. Berdasarkan pendapat Cholik (Cholik, 2017) guru sebagai sumber tunggal dalam belajar, sehingga hal tersebut secara tidak langsung akan membatasi sikap aktif peserta didik dalam mencari materi suatu pelajaran, karena peserta didik sudah terbiasa hanya menunggu materi yang diberikan oleh gurunya.

Penelitian mengenai pengembangan LKPD ini sudah pernah dilakukan oleh Asri Puspitasari dalam (Puspitasari \& Handziko, 2018) yang memperoleh hasil bahwa penerapan aplikasi LKPD mobile learning berbasis guided discovery secara statistik dapat meningkatkan hasil penguasaan kompetensi dasar (pengetahuan dan keterampilan) peserta didik. Sementara

Jurnal Sikola: Jurnal Kajian Pendidikan dan Pembelajaran Vol. 3, No. 1, Th. 2021 
penelitian Laras Auliantika Hapsari (Hapsari, 2018) mengungkapkan produk LKPD yang dihasilkan layak digunakan dalam pembelajaran, efektif meningkatkan pemahaman konsep peserta didik, namun kurang efektif dalam meningkatkan sikap peduli lingkungan karena hanya diujicoba sebanyak tiga kali pertemuan. Penelitian sebelumnya memberikan studi literatur pada peneliti mengenai tahapan pengembangan LKPD baik yang dapat digunakan secara online ataupun cetak.

Penyusunan LKPD dapat meliputi beberapa unsur yang harus ada didalamnya. Penggunaan unsur-unsur tersebut tergantung dari pengembang yang akan menggunakannya seperti judul, kompetensi dasar, informasi pendukung, tugas atau langkah kerja, dan penilaian. Penyusunan LKPD tentunya dapat dirancang secara mandiri oleh guru dengan melakukan analisis kurikulum, berupa kompetensi inti, kompetensi dasar dan materi pelajaran, selanjutnya menyusun peta kebutuhan LKPD, menetapkan judul LKPD, mendesain LKPD serta menentukan alat penilaian LKPD tersebut. (Noor, 2017). Pengembangan LKPD yang dilakukan oleh guru secara mandiri hendaknya mempunyai inovasi dan mendukung untuk untuk meningkatkan penguasaan materi peserta didik. Inovasi yang dilakukan berupa LKPD ini akan dilengkapi dengan materi dan penugasan. Penelitian terdahulu dan konsep-konsep yang dikemukakan oleh ahli memberikan sumbangan pada penelitian ini sehingga peneliti dapat memfokuskan penelitian ini pada pengembangan LKPD sosiologi yang kontektual sehingga dapat digunakan oleh peserta didik kelas $\mathrm{X}$ agar mereka mampu mengkonstruksi konsep dari fenomena sosial yang mereka amati setelah mengikuti pembelajaran berbasis model discovery learning.

\section{Metode Penelitian}

Penelitian ini menggunakan pendekatan kuantitatif tipe penelitian Research and Development yaitu suatu metode penelitian yang digunakan untuk menghasilkan produk tertentu, dan menguji keefektifan produk tersebut (Sugiyono 2010) dalam (Nurhalimah, Suhartono, \& Cahyana, 2017). Tipe penelitian ini dipilih untuk menghasilkan Lembar Kerja Peserta Didik (LKPD) yang layak digunakan dalam pembelajaran sosiologi, agar dapat mengetahui peningkatan penguasaan materi peserta didik SMA N 2 Payakumbuh setelah mengikuti pembelajaran dan penugasa kontekstual berbasis model discovery learning.

Lembar kerja peserta didik (LKPD) yang dikembangkan menggunakan model pengembangan 4-D (Four D Models) yang terdiri atas: (1) define (pendefinisian), (2) design (perancangan), (3) develop (pengembangan), dan (4) disseminate (penyebaran). Thiagarajan dan Semmel dalam (Setiabudi, Susanta, \& Maulidiya, 2019). Tahap pertama ada deffine tahap pendefinisian ini digunakan untuk menjelaskan syarat-syarat yang dibutuhkan dalam pengembangan pembelajaran. Tahap penjelasan atau pendefinisian ini mencakup lima langkah inti, yaitu meliputi: (1) analisis awal, (2) analisis peserta didik, (3) analisis tugas atau (4) analisis konsep, serta (5) rumusan dari tujuan pembelajaran. Selanjutnya pada tahap design tahap perancangan ini merupakan tahap dimana membuat suatu rancangan pengembangan bahan ajar Lembar Kerja Peserta Didik (LKPD) hal yang perlu dirancang dalam penelitian ini yaitu: (a) menyusun rancangan instrumen penilaian yang dikembangkan sesuai dengan materi (b) menyusun perangkat pembelajaran seperti RPP, dan instrumen pengambilan data seperti angket validasi oleh ahli ada lembar validasi soal, dan lembar validasi produk, angket validasi praktikalitas (c) memilih tampilan format dari instrumen penilaian yang akan dikembangkan. Tahap develop tahap ini berguna untuk mengembangkan serta memperbaiki rancangan produk yang ingin dikembangkan, ada dua alangkah yang perlu dilakukan yaitu (a) penilaian ahli yang kemudian akan direvisi (b) uji coba pengembangan yang terakhir ada tahap disseminate tahap ini adalah tahap dimana penyebaran pada perangkat sudah dilakukan. Proses penyebaran dilaksanakan agar supaya dapat meningkatkan hasil belajar peserta didik dalam belajar dan penguasaan materi.

Jurnal Sikola: Jurnal Kajian Pendidikan dan Pembelajaran Vol. 3, No. 1, Th. 2021 
Teknik pengumpulan data dilakukan melalui wawancara terhadap guru, tata usaha dan wakil kepala sekolah untuk mengetahui kondisi awal proses pembelajaran sosiologi di SMAN 2 Payakumbuh. Selain itu peneliti juga melakukan observasi pada saat proses pembelajaran dan peserta didik kelas X SMAN 2 Payakumbuh, yang terdiri dari beberapa beberapa tahapan, yaitu observasi awal dilakukan terhadap proses pembelajaran, menguji kelayakan LKPD, memberikan angket respon peserta didik, observasi keterampilan proses untuk mengetahui keterampilan proses, dan selanjutnya peneliti mengumpulkan data kuantitatif melalui pemberian soal pretest dan posttest untuk mengetahui peningkatan penugasan materi peserta didik, serta angket praktikalitas LKPD yang dirancang kepada guru dan speserta didik.

Populasi pada penelitian ini terdiri dari 114 peserta didik kelas X IPS 2 di SMA N 2 Payakumbuh dan sampel pada penelitian yang digunakan adalah sebanyak 38 peserta didik pada kelas X IPS 1 . Berikut gambaran populasi dan sampel penelitian.

Tabel 2. Jumlah Peserta Didik

\begin{tabular}{cc}
\hline Kelas & Peserta Didik \\
\hline X IPS 1 & 38 \\
\hline X IPS 2 & 38 \\
\hline X IPS 3 & 38 \\
\hline Jumlah Peserta didik & 114 \\
\hline
\end{tabular}

Instrumen penelitian terdiri dari instrumen pembelajaran dan instrumen pengumpulan data yang sudah divalidasi oleh validator ahli dan validator praktisi sehingga diperoleh instrumen yang valid dan reliabel. Instrumentasi perangkat pembelajaran meliputi (a) silabus dan rancangan pelaksanaan pembelajaran (RPP) (b) lembar kerja peserta didik (LKPD) selanjutnya ada instrumen pengambilan data meliputi (a) lembar validasi perangkat pembelajaran lembar kerja peserta didik (LKPD) (b) lembar validasi RPP (b) lembar validasi soal pretest dan posttest (c) lembar angket praktikalitas guru (d) lembar angket praktikalitas peserta didik.

Uji validitas 20 buah soal pretest dan posttest, angket praktikalitas, dan angket validitas ahli materi, media dan praktisi dilakukan dengan menggunakan SPSS dengan rumus Analysz Frequence. Uji validitas ini dilakukan untuk melihat apakah seluruh instrumen yang digunakan layak diujicobakan atau tidak.

\section{Hasil dan Pembahasan}

\section{Hasil Penelitian}

Hasil belajar peserta didik menunjukkan kemampuan dan kualitas peserta didik sebagai dampak dari proses pembelajaran yang telah dilaluinya. Melton menyiratkan bahwa hasil belajar merupakan tindakan dan pertunjukan yang mengandung dan mencerminkan kompetensi peserta didik yang berhasil menggunakan konten, informasi, ide-ide dan alat-alat dalam pembelajaran. Oleh karena itu hasil belajar dapat didefenisikan sebagai kompetensi dan keterampilan yang dimiliki peserta didik setelah masa pembelajaran (Molstad \& Karseth, 2016) dalam (Nurhasanah \& Sobandi, 2016). Dapat dikatakan bahwa adanya hasil belajar peserta didik yang tinggi dan berkualitas, dihasilkan dari proses pembelajaran yang berkualitas, untuk menghasilkan proses pembelajaran yang berkualitas seorang tenaga pendidik membutuhkan kemampuan dalam menerapkan metode pembelajaran yang sesuai dengan kebutuhan dalam kelas, ketidaksesuaian metode pembelajaran yang diterapkan dapat menurunkan kualitas proses pembelajaran itu sendiri, dengan demikan dalam penelitian ini ingin mengetahui dan menganalisis mengenai penggunaan metode pembelajaran dalam peningkatan hasil belajar peserta didik di sekolah.(Nasution, 2017).

Lembar Kerja Peseta Didik (LKPD) ini dikembangkan menggunakan model pengembangan 4-D (Four D Models) Seperti yang dikemukakan oleh Thiagarajan dan Semmel dalam (Setiabudi et al., 
2019). mereka desain penelitian pengembangan 4-D terdiri atas: (1) define (pendefinisian), (2) design (perancangan), (3) develop (pengembangan), dan (4) disseminate (penyebaran).

\section{Tahap Define (Pendefinisian)}

Tahap pendefinisian ini digunakan untuk menjelaskan syarat-syarat yang dibutuhkan dalam pengembangan pembelajaran. Syarat digunakan dengan memperhatikan serta menyesuaiakan kebutuhan pembelajaran sosiologi mengenai permasalahan kegiatan pembelajaran serta dibatasi pada materi pokok perilaku menyimpang di masyarakat. Tahap penjelasan atau pendefinisian ini mencakup lima langkah inti, yaitu meliputi: (1) analisis awal, (2) analisis peserta didik, (3) analisis tugas atau (4) analisis konsep, serta (5) rumusan dari tujuan pembelajaran.

\section{Tahap Design (Perancangan)}

Pada tahap perancangan ini membuat suatu rancangan pengembangan LKPD materi perilaku menyimpang yang dapat digunakan peserta didik kelas X SMA N serta menyusun rancangan instrumen pengumpulan data. Beberapa hal prinsip yang peneliti lakukan dalam produk penelitian ini yaitu:

a. Menyusun rancangan instrumen penilaian yang ingin dikembangkan sejalan dengan tujuan dan materi pembelajaran perilaku menyimpang di masyarakat.

b. Menyusun rancangan instrumen penelitian yang diantaranya perangkat pembelajaran dan instrumen pengambilan data yang akan digunakan antara lain yaitu, angket validasi oleh ahli ada lembar validasi soal dan lembar validasi produk, angket validasi praktikalitas dari peserta didik dan guru. Instrumen pengambilan data ini yang kemudian akan dikonsultasikan kepada dosen pembimbing yang nanti akan bisa dipakai untuk memvalidasi instrumen pembelajaran dan juga instrumen pengambilan data.

c. Memilih tampilan format dari instrumen penilaian yang akan dikembangkan.

Adapun desain sumber belajar LKPD yang dikembangkan dapat dilihat pada gambar berikut ini.

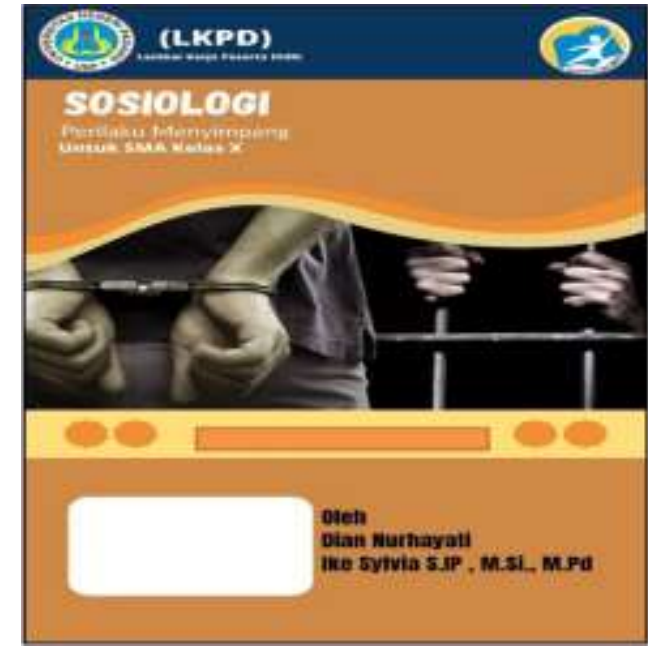

Gambar 1. Desain Cover LKPD

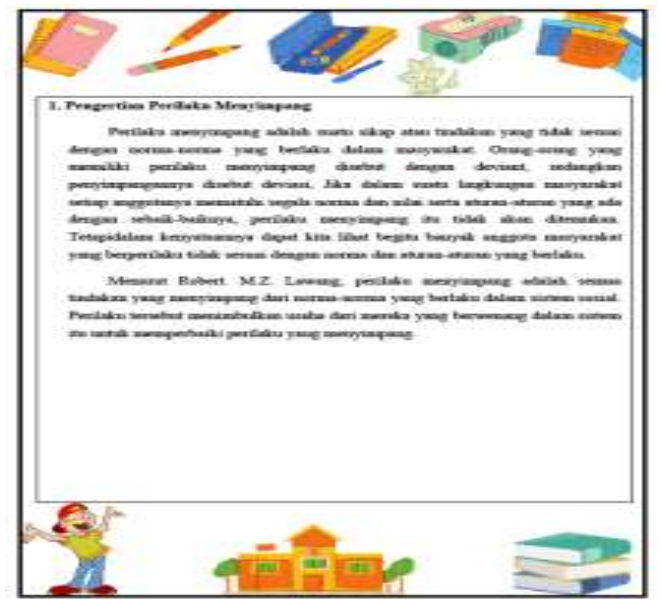

Gambar 2. Pengembangan Komponen Materi pada LKPD

Jurnal Sikola: Jurnal Kajian Pendidikan dan Pembelajaran Vol. 3, No. 1, Th. 2021 

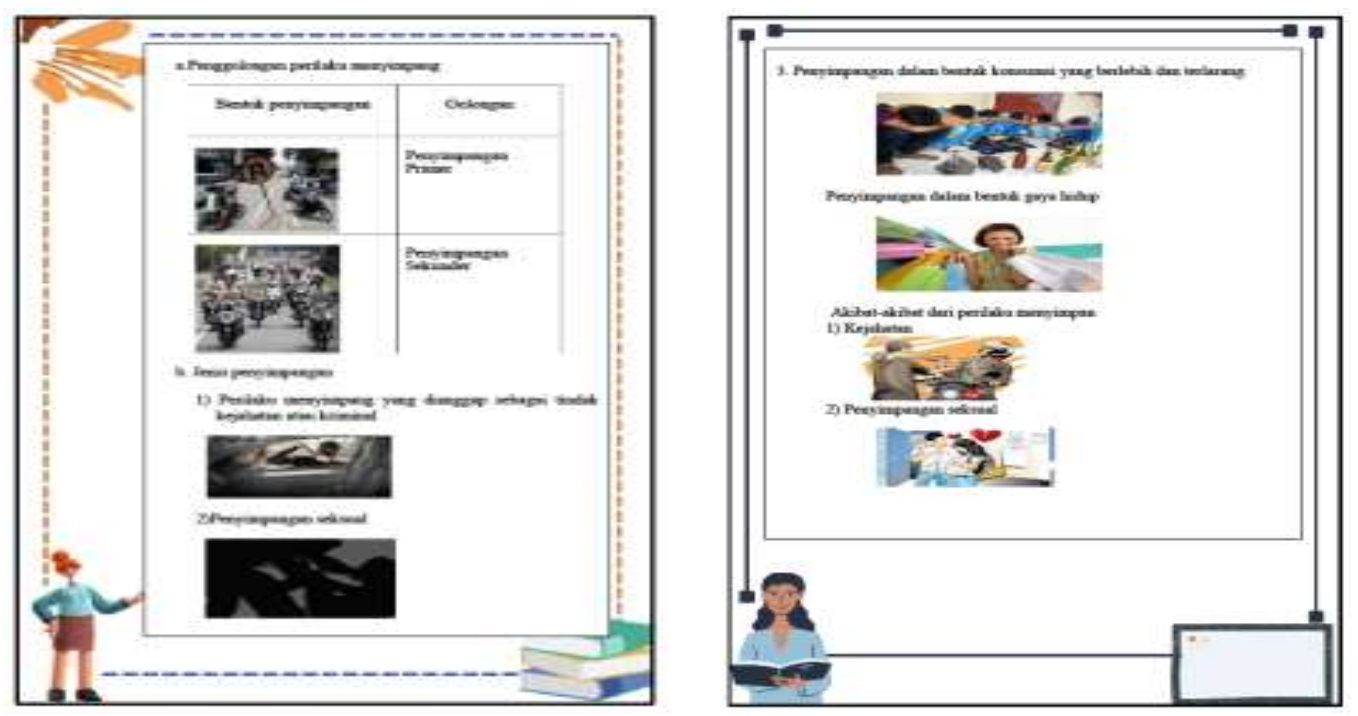

Gambar 3. Pengembangan Komponen Penugasan pada LKPD
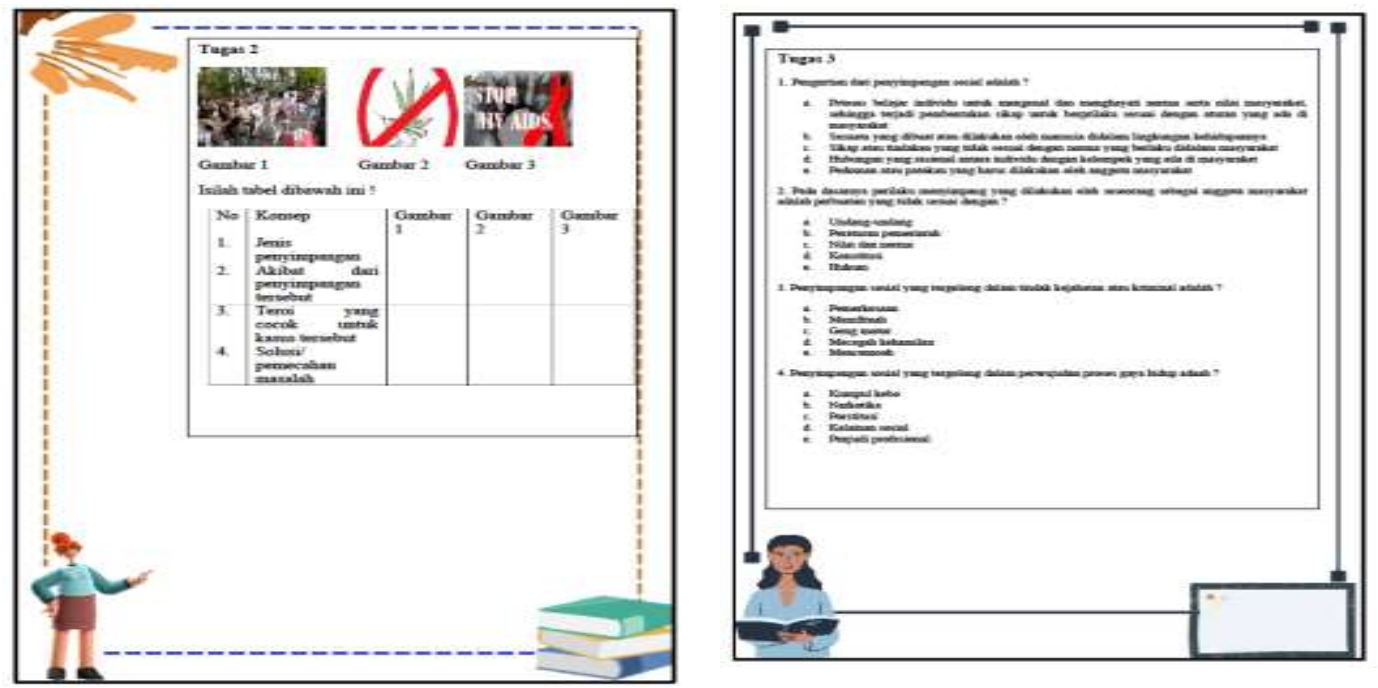

Gambar 4. Pengembangan Komponen Evaluasi pada LKPD

\section{Tahap Develop (Pengembangan)}

Tahap ini berguna untuk penyempurnaan rancangan produk yang telah dirancang dengan mendapatkan masukan ahli dan praktisi. Berikut tahapan membuat lembar kerja peserta didik yaitu:

\section{Validasi LKPD dan Soal}

Validasi dilakukan oleh 3 orang ahli yaitu, ahli media, materi dan praktisi yaitu guru. Materi perilaku menyimpang yang terdapat pada LKPD yang dikembangkan divalidasi oleh ahli materi berdasarkan 7 indikator dan hasilnya dapat dilihat pada tabel di bawah ini. Adapun hasil validasi memperlihatkan kelemahan LKPD yang dirancang pada aspek fakta yang dikemukakan belum bervariatif sesuai dengan penjelasan untuk setiap konsep yang harus dipahami oleh peserta didik. 
Dian Nurhayati, Ike Sylvia Pengembangan Lembar Kerja Peserta Didik (LKPD) Sosiologi Kelas X SMA Berbasis Discovery Learning

Tabel 3. Rata-rata Skor Angket Validasi LKPD dari Aspek Materi

\begin{tabular}{llc}
\hline No & \multicolumn{1}{c}{ Aspek yang dinilai } & Rata-rata Skor \\
\hline 1 & $\begin{array}{l}\text { Konsep materi yang disajikan sesuai dengan kompetensi inti, } \\
\text { kompetensi dasar, indikator pencapaian kompetensi, tujuan } \\
\text { pembelajaran lengkap dan mudah dipahami pada materi }\end{array}$ & 92 \\
\hline 2 & $\begin{array}{l}\text { Materi yang disajikan secara keseluruhan mewakili cakupan } \\
\text { materi dan sesuai dengan jenjang pendidikan kelas X SMA }\end{array}$ & 92 \\
\hline 3 & $\begin{array}{l}\text { Kegiatan pembelajaran pada LKPD dapat meningkatkan } \\
\text { penguasaan materi peserta didik }\end{array}$ & 92 \\
\hline 4 & \begin{tabular}{l} 
Ketetapan materi yang disajikan sesuai dan mudah dipahami \\
\hline 5
\end{tabular} & $\begin{array}{l}\text { Materi dan permasalahan yang disajikan relevan antara fakta } \\
\text { yang disajikan dengan konsep }\end{array}$ \\
\hline 6 & $\begin{array}{l}\text { Pengembangan konsep yang berkaitan dengan kehidupan } \\
\text { sehari-hari }\end{array}$ & 92 \\
\hline 7 & $\begin{array}{l}\text { Keesuaian contoh materi dengan indikator pencapaian } \\
\text { kompetensi. }\end{array}$ & 75 \\
\hline & \multicolumn{2}{c}{ Rata-rata } \\
\hline
\end{tabular}

Sumber: Data Primer (2021)

Aspek berikutnya yang yang divalidasi adalah tampilan LKPD dengan mengacu pada 12 indikator, dengan hasil validasi dapat dilihat pada tabel di bawah ini.

Tabel 4. Rata-rata Skor Angket Validasi LKPD dari Aspek Materi

\begin{tabular}{clc}
\hline No & \multicolumn{1}{c}{ Aspek yang dinilai } & Rata-rata Skor \\
\hline 1 & Penggunaan struktur kalimat jelas & 85 \\
\hline 2 & Penggunaan struktur kalimat yang pendek dan sederhana & 85 \\
\hline 3 & Bahasa yang digunakan sudah baku dan mudah dipahami & 80 \\
\hline 4 & $\begin{array}{l}\text { Bahasa yang digunakan sesuai dengan tingkat perkembangan } \\
\text { kedewasaan peserta didik }\end{array}$ & 100 \\
\hline 5 & Kesesuaian dengan warna & 80 \\
\hline 6 & Cover/sampul & 60 \\
\hline 7 & Kejelasan tulisan & 85 \\
\hline 8 & Kejelasan gambar & 85 \\
\hline 9 & Keringkasan, kesederhanaan, dan dibatasi pada hal-hal penting & 85 \\
\hline 10 & Keseimbangan garis, bentuk, ruang, tulisan, dan gambar & 80 \\
\hline 11 & $\begin{array}{l}\text { Menyediakan ruang yang cukup untuk menulis dengan leluasa } \\
\text { pada LKPD }\end{array}$ & 80 \\
\hline 12 & Mempunyai identitas untuk memudahkan administrasi guru & 85 \\
\hline & \multicolumn{2}{c}{ Rata-rata } \\
\hline
\end{tabular}

Sumber: Data Primer (2021)

Penilaian validasi soal pretest-posttest ini dinilai oleh dosen ahli. Penilaian dari validasi soal itu memiliki 3 aspek, berikut penjelasan hasil validasi soal 
Tabel 5. Rata-rata Skor Angket Validasi Soal

\begin{tabular}{|c|c|c|}
\hline No & Aspek yang dinilai & Rata-rata Skor \\
\hline \multicolumn{3}{|c|}{ Konstruksi Soal } \\
\hline 1 & $\begin{array}{l}\text { Tingkat kesulitan soal sesuai dengan tingkat } \\
\text { pola pikir peserta didik }\end{array}$ & 83 \\
\hline 2 & $\begin{array}{l}\text { Tingkat kejelasan rumusan pokok soal sesuai } \\
\text { dengan tingkat pola pikir peserta didik }\end{array}$ & 92 \\
\hline 3 & $\begin{array}{l}\text { Tingkat kejelasan rumusan pilihan jawaban } \\
\text { sesuai dengan tingkat pola pikir peserta didik }\end{array}$ & 83 \\
\hline \multirow[t]{3}{*}{4} & $\begin{array}{l}\text { Tingkat kesesuaian butir soal sesuai dengan } \\
\text { indikator sesuai dengan tingkat pola pikir } \\
\text { peserta didik }\end{array}$ & 83 \\
\hline & Rata-rata & 85,42 \\
\hline & Keterangan & Sangat baik \\
\hline \multicolumn{3}{|c|}{ Materi } \\
\hline 5 & Materi yang disampaikan lengkap & 83 \\
\hline 6 & $\begin{array}{l}\text { Materi yang disampaikan dapat meluaskan } \\
\text { pengetahuan peserta didik }\end{array}$ & 92 \\
\hline 7 & $\begin{array}{l}\text { Tingkat keakuratan konsep dan definisi materi } \\
\text { sesuai }\end{array}$ & 92 \\
\hline 8 & Materi dan contoh akurat & 92 \\
\hline 9 & Keaakuratan data dan fakta materi sesuai & 92 \\
\hline \multirow[t]{3}{*}{10} & $\begin{array}{l}\text { Menggunakan contoh dan kasus yang terdapat } \\
\text { dalam kehidupan sehari-hari }\end{array}$ & 51 \\
\hline & Rata-rata & 83,43 \\
\hline & Keterangan & Sangat baik \\
\hline \multicolumn{3}{|c|}{ Kualitas Soal } \\
\hline 11 & $\begin{array}{l}\text { Tingkat keterbacaan soal sesuai dengan tingkat } \\
\text { pola pikir peserta didik }\end{array}$ & 92 \\
\hline 12 & $\begin{array}{l}\text { Tingkat pemahaman soal sesuai dengan tingkat } \\
\text { pemahaman peserta didik }\end{array}$ & 92 \\
\hline 13 & Keseimbangan ilustrasi dan kasus soal sesuai & 92 \\
\hline \multirow[t]{3}{*}{14} & $\begin{array}{l}\text { Kesesuaian tingkat level kognitif soal sesuai } \\
\text { dengan pola pikir peserta didik. }\end{array}$ & 92 \\
\hline & Rata-rata & 91,67 \\
\hline & Keterangan & Sangat baik \\
\hline
\end{tabular}

Sumber: Data Primer (2021)

\section{Praktikalitas LKPD}

Angket praktikalitas LKPD yang dikembangkan ini diisi oleh guru dan peserta didik yang sudah menggunakan LKPD dalam pembelajaran. Untuk mengukur praktikalitas LKPD ini dari berdasarkan penilaian guru, maka peneliti mengembangkan tiga aspek, yaitu aspek pembelajaran, aspek kesederhanaan penggunaan, dan aspek kesesuain KI dan KD serta mengembangkannya menjadi iindikator, dengan penjabaran hasil seperti pada tabel di bawah ini. 
Dian Nurhayati, Ike Sylvia Pengembangan Lembar Kerja Peserta Didik (LKPD) Sosiologi Kelas X SMA Berbasis Discovery Learning

Tabel 6. Rata-rata Skor Angket Praktikalitasa LKPD oleh Guru

\begin{tabular}{|c|c|c|}
\hline No & Aspek yang dinilai & Rata-rata Skor \\
\hline \multicolumn{3}{|c|}{ Praktikalitas Penggunaan dalam Pembelajaran } \\
\hline 1 & $\begin{array}{l}\text { Menggunakan LKPD dapat meningkatkan } \\
\text { penguasaan materi pada peserta didik }\end{array}$ & 100 \\
\hline 2 & $\begin{array}{l}\text { Menggunakan LKPD dapat meningkatkan minat } \\
\text { belajar peserta didik }\end{array}$ & 100 \\
\hline 3 & $\begin{array}{l}\text { Menggunakan LKPD ini dapat membuat peserta } \\
\text { didik aktif dalam proses pembelajaran }\end{array}$ & 100 \\
\hline 4 & $\begin{array}{l}\text { Menggunakan LKPD ini meningkatkan hasil belajar } \\
\text { peserta didik }\end{array}$ & 100 \\
\hline 5 & $\begin{array}{l}\text { LKPD ini mengutamakan keterlibatan peserta didik } \\
\text { dalam proses pembelajaran }\end{array}$ & 100 \\
\hline \multirow[t]{3}{*}{6} & $\begin{array}{l}\text { LKPD ini mudah diaplikasikan oleh guru dalam } \\
\text { proses pembelajaran }\end{array}$ & 100 \\
\hline & Rata-rata & 100 \\
\hline & Keterangan & Sangat Praktis \\
\hline \multicolumn{3}{|c|}{ Kesederhanaan Penggunaan } \\
\hline & $\begin{array}{l}\text { LKPD ini efektif dan efisien untuk digunakan } \\
\text { dalam proses pembelajaran }\end{array}$ & 100 \\
\hline & Rata-rata & 100 \\
\hline & Keterangan & Sangat Praktis \\
\hline \multicolumn{3}{|c|}{ Kesesuaian KI dan KD } \\
\hline 9 & $\begin{array}{l}\text { LKPD sesuai dengan KD (Kompetensi Dasar) yang } \\
\text { diajarkan }\end{array}$ & 100 \\
\hline 10 & LKPD ini bisa memberikan contoh yang relevan & 100 \\
\hline & Rata-rata & 100 \\
\hline & Keterangan & Sangat Baik \\
\hline
\end{tabular}

Sumber: Data Primer (2021)

Selanjutnya peneliti juga mengukur kepraktisan LKPD ini berdasarkan penilaian peserta didik, dengan mengukur pendapat peserta didik terhadap LKPD ini dari tiga aspek, yaitu: aspek media pembelajaran, kendala belajar peserta didik, dan proses belajar peserta didik.

Tabel 6. Rata-rata Skor Angket Praktikalitasa LKPD oleh Peserta Didik

\begin{tabular}{clc}
\hline No & \multicolumn{1}{c}{ Aspek yang dinilai } & Rata-rata Skor \\
\hline Praktikalitas Media Pembelajaran & 91 \\
\hline 1 & $\begin{array}{l}\text { Ketertarikan mengikuti pelajaran sosiologi karena } \\
\text { menggunakan lembar kerja peserta didik }\end{array}$ & 90 \\
\hline 2 & $\begin{array}{l}\text { Ketertarikan mneggunakan LKPD karena dengan } \\
\text { belajar dengan lembar kerja peserta didik } \\
\text { menjadikan lebih semangat dalam menjawab } \\
\text { pertanyaan }\end{array}$ & 83 \\
\hline 3 & Minat peserta didik menggunakan LKPD & 89 \\
\hline 4 & $\begin{array}{l}\text { Ketertarikan menggunakan LKPD karena didalam } \\
\text { tugasnya ada mengamati gambar tentang materi } \\
\text { yang diberikan }\end{array}$ & 90 \\
\hline 5 & $\begin{array}{l}\text { Ketertarikan menggunakan LKPD karena lebih } \\
\text { mudah memahaminya dengan adanya gambar }\end{array}$ & \\
\hline
\end{tabular}

Jurnal Sikola: Jurnal Kajian Pendidikan dan Pembelajaran Vol. 3, No. 1, Th. 2021 


\begin{tabular}{|c|c|c|}
\hline \multicolumn{3}{|c|}{ didalam materi } \\
\hline & Rata-rata & 88,36 \\
\hline & Keterangan & Sangat Praktis \\
\hline \multicolumn{3}{|c|}{ Kendala Belajar Peserta Didik } \\
\hline 6 & $\begin{array}{l}\text { Keantusiaan mengikuti pembelajaran dengan } \\
\text { menggunakan sumber belajar LKPD }\end{array}$ & 48 \\
\hline \multirow[t]{3}{*}{7} & Kebingungan saat mengerjakan tugas pada LKPD & 49 \\
\hline & Rata-rata & 48,32 \\
\hline & Keterangan & Cukup Praktis \\
\hline \multicolumn{3}{|c|}{ Proses Belajar Peserta Didik } \\
\hline 8 & $\begin{array}{l}\text { Minat peserta didik dalam pembelajaran karena } \\
\text { menggunakan sumber belajar LKPD }\end{array}$ & 85 \\
\hline 9 & $\begin{array}{l}\text { Kepuasan dengan pelaksanaan dan desain dari } \\
\text { sumber belajar LKPD }\end{array}$ & 86 \\
\hline \multirow[t]{3}{*}{10} & $\begin{array}{l}\text { Senang dengan tugas mengamati gambar tentang } \\
\text { materi yang ada pada LKPD }\end{array}$ & 89 \\
\hline & Rata-rata & 86,67 \\
\hline & Keterangan & Sangat Praktis \\
\hline
\end{tabular}

Instrumen pengambilan data yang akan digunakan antara lain yaitu, angket validasi oleh ahli ada lembar validasi media, lembar validasi angket praktikalitas dari peserta didik dan guru. Tujuan lainnya dari validasi agar bisa mendapatkan saran atau masukan untuk memperbaiki media belajar yang dikembangkan.

\section{Tahap Disseminate (Penyebaran)}

Tahap ini adalah tahap dimana penyebaran dilaksakan untuk melihat efektifitas produk yang dihasilkan. Analisis Efektivitas ini diperoleh dari hasil uji beda skor pretest dan posttest menggunakan rumus Uji T yang diolah melalui aplikasi SPSS. Sebelum melakukan uji T, peneliti terlebih dahulu melakukan uji normalitas dan homogenitas data dari skor pretest dan posttest. Berikut hasil uji normalitas data.

Tabel 7. Uji Normalitas

\begin{tabular}{llr}
\hline \multicolumn{3}{c}{ One-Sample Kolmogorov-Smirnov Test } \\
\hline N & Unstandardized Residual \\
\hline Normal Parameters ${ }^{\mathrm{a}, \mathrm{b}}$ & Mean & 38 \\
\cline { 2 - 3 } & Std. Deviation &, 000 \\
\hline Most Extreme Differences & Absolute & 4,859 \\
\cline { 2 - 3 } & Positive &, 085 \\
\cline { 2 - 3 } & Negative &, 085 \\
\hline Test Statistic &,- 084 \\
\hline Asymp. Sig. (2-tailed) &, 085 \\
\hline a. Test distribution is Normal. &, $200^{\text {c,d }}$ \\
\hline b. Calculated from data. & \\
\hline c. Lilliefors Significance Correction. & \\
\hline d. This is a lower bound of the true significance. &
\end{tabular}

Sumber: Data Primer (2021)

Analisis data dari tabel di atas menyatakan bahwa skor pretest dan posttest terdistribusi secara normal, hal ini dibuktikan dengan nilai sig pada Kolmogorov-Smimov $>$ dari 0,05. Berikut ini tabel homogenitas data skor pretest dan posttest peserta didik kelas X IPS 1 SMA N 2 Payakumbuh: 
Tabel 8. Uji Homogenitas

\begin{tabular}{|c|c|c|c|c|c|}
\hline \multicolumn{6}{|c|}{ Test of Homogeneity of Variances } \\
\hline & & Levene & & & \\
\hline & & Statistic & df1 & df2 & Sig. \\
\hline \multirow{4}{*}{$\begin{array}{l}\text { nilai } \\
\text { pretest } \\
\text { posttes }\end{array}$} & Based on Mean & 3,448 & 1 & 74 & ,067 \\
\hline & Based on Median & 3,201 & 1 & 74 &, 078 \\
\hline & $\begin{array}{l}\text { Based on Median and } \\
\text { with adjusted df }\end{array}$ & 3,201 & & 62,963 & 078 \\
\hline & Based on trimmed mean & 3,495 & 1 & 74 & 066 \\
\hline
\end{tabular}

Dari kedua data SPSS diatas terlihat bahwa nilai pretest dan posttest homogen, hal ini dibuktikan dengan sig $>0,5$. Sehingga bisa dikatakan data pretest dan posttest peserta didik kelas $\mathrm{X}$ IPS 1 SMA N 2 Payakumbuh normal dan homogen dan dapat dicari efektfitas LKPD yang dikembangkan menggunakan uji T-Test. Berikut hasil analisis Uji T-Test

Tabel 9. Hasil Uji T Skor Pretest dan Posttest setelah Mengikuti Pembelajaran Berbantuan LKPD

\begin{tabular}{|llll|c|c|}
\hline \multicolumn{6}{c}{ Paired Samples Statistics } \\
\hline \multicolumn{7}{c}{ Mean } & N & Std. Deviation & $\begin{array}{c}\text { Std. Error } \\
\text { Mean }\end{array}$ \\
\hline Pair 1 & $\begin{array}{l}\text { Pre } \\
\text { Test }\end{array}$ & 65,7895 & 38 & 12,86764 & 2,08741 \\
\cline { 2 - 6 } & $\begin{array}{l}\text { Post } \\
\text { Test }\end{array}$ & 88,6842 & 38 & 7,59482 & 1,23204 \\
\hline \multicolumn{6}{|c|}{ Paired Samples Correlations } \\
\hline Pair 1 & $\begin{array}{l}\text { Pre Test \& Post } \\
\text { Test }\end{array}$ & N & Correlation & Sig. \\
\hline
\end{tabular}

Sumber: Data Primer (2021)

Dari hasil pretest dan posttest mendapatkan hasil Sig (2-tailed) yaitu 0,00 (maka Ho ditolak dan Ha diterima) dan dapat dipahami jika terdapat perbedaan rata-rata pada hasil belajar pretest dan posttest setelah menggunakan LKPD yang peneliti kembangkan. Secara keseluruhan temuan penelitian, LKPD yang dikembangkan ini valid, karena telah divalidasi baik LKPD dan soalnya, praktis digunakan oleh guru dan peserta didik, serta efektif meningkatkan hasil belajar peserta didik pada materi materi perilaku menyimpang yang diujicobakan pada kelas X IPS 1 SMA N 2 Payakumbuh.

\section{Pembahasan}

Berdasarkan dari hasil penelitian pengembangan LKPD yang diuji cobakan dengan model pembelajaran discovery learning dapat diterapkan dalam pembelajaran sosiologi SMA khususnya kelas X materi perilaku menyimpang. LKPD ini menyediakan petunjuk penggunaan dan penugasan yang memberikan peserta didik pengalaman belajar yang dapat membantu yang dijadikan panduan peserta didik untuk melakukan penyelidikan atau pemecahan masalah. Adapun komponen yang ada dalam LKPD ini telah sesuai dengan syarat LKPD yang daapt menstimuli kopetensi peserta didik yaitu terdiri dari bagian awal seperti judul, mata pelajaran, semester, tempat, diikuti dengan petunjuk belajar, kompetensi yang akan dicapai, indikator 
pembelajaran, informasi pendukung, alat dan bahan dalam mengerjakan LKPD, petunjuk belajar, langkah kerja, dan penilaian. (Elfina \& Sylvia, 2020)

Peserta didik juga dapat menemukan arahan yang terstruktur untuk memahami materi yang diberikan dan peserta didik diberikan tugas yang berkaitan dengan materi tersebut (Prastowo, 2012: 204). Pembelajaran dengan menggunakan LKPD akan lebih efektif jika terdapat teori maupun praktik, LKPD juga praktis digunakan dalam pembelajaran sebagai bahan ajar karena pada saat pembelajaran peserta didik tidak perlu membeli dan pengerjaannya, tidak membosankan karena di desain dengan sangat menarik sehingga peserta didik tidak jenuh ataupun bosan dalam pembelajaran.

Pengembangan LKPD ini valid, praktis dan efektif karena dirancang mengikuti prinsip teori konstruktivistik, dimana konten dan alur belajar peserta didik pada LKPD ini sifatnya membangun, membangun dari segi kemampuan, pemahaman, dalam proses pembelajaran. Sebab dengan memiliki sifat membangun maka dapat diharapkan keaktifan dari pada peserta didik akan meningkat kecerdasannya. Pembelajaran yang dialami oleh peserta didik dapat menstimuli aktivitas mereka, di mana peserta didik membina sendiri pengetahuannya, mencari arti dari apa yang mereka pelajari, dan merupakan proses menyelesaikan konsep dan ide-ide baru dengan kerangka berfikir yang telah ada dimilikinya, maka LKPD ini sesuai dengan aturan yang menjadi pedoman dalam kurikukum 2013 yang menuntut peserta didik untuk aktif dan kreatif dengan

\section{Kesimpulan}

Berdasarkan hasil penelitian dan pembahasan, maka dapat ditarik kesimpulan telah dihasilkan Lembar Kerja Peserta Didik (LKPD) berbasis Discovery Learning yang valid, praktis dan efektif sehingga dapat dipergunakan dalam proses pembelajaran sosiologi di SMA khusunya kelas $\mathrm{X}$ materi perilaku menyimpang. Adapun persentase rata-rata skor validasi LKPD ini adalah $86,4 \%$ (sangat baik). rata-rata skor praktikalitas guru 100\% (sangat baik), cobakan menggunakan model praktis bisa dipergunakan oleh peserta didik dengan rentang persentase $64 \%$ - $65,2 \%$ dengan kategori cukup praktis. LKPD dinyatakan efektif meningkatkan hasil belajar peserta didik karena terdapat perbedaan skor pretest dan posttest dari hasil uji $\mathrm{T}$ serta menggunakan program SPSS versi 26 Paired T-Test dengan hasil Sig (2-tailed) yaitu 0.00 yang dimaknai bahwa ada terdapat perbedaan rata-rata soal pretest dan posttest peserta didik.

\section{Daftar Pustaka}

Apriyada, P. (2017). Belajar Dan Pembelajaran Aprida Pane Muhammad Darwis Dasopang. 03(2), 333352.

Cholik, C. A. (2017). Pemanfaatan Teknologi Informasi dan Komunikasi Untuk Meningkatkan pendidikan di Indonesia. Jurnal Ilmiah Indonesia, 2.

Dwi, Y., Sagala, A., Simanjuntak, M. P., Bukit, N., Dwi, Y., Sagala, A., ... Bukit, N. (2019). Penerapan Project Based Learning Berbasis LKS Terhadap Keterampilan Berpikir Kritis Siswa.

Elfina, S., \& Sylvia, I. (2020). Pengembangan Lembar Kerja Peserta Didik (LKPD) Berbasis Problem Based Learning (PBL) dalam Meningkatkan Kemampuan Berpikir Kritis Siswa Pada Mata Pelajaran Sosiologi di SMA Negeri 1 Payakumbuh. Jurnal Sikola: Jurnal Kajian Pendidikan Dan Pembelajaran, 2(1), 27-34. https://doi.org/10.24036/sikola.v2i1.56

Ermi Netti. (2010). penggunaan media LKS dalam Meningkatkan Hasil Belajar Siswa. Pendidikan.

Frastiyanti, I. (2017). Pengembangan LKPD Berbasis Conceptual Attainment Untuk Meningkatkan Hasil Belajar Ranah Kognitif dan Keterampilan Proses Sains Peserta Didik Kelas X SMA Pada Materi Pokok Hukum Newton Tentang Gerak.

Frastiyanti, I. (2018). Peraturan Menteri Pendidikan dan Pendidikan Republik Indonesia. Jdih.Kemdikbud.Go.Id.

Hapsari, L. A. (2018). Pengembangan Lembar Kerja Peserta Didik (LKPD) Berbasis Kearifan Lokal

Jurnal Sikola: Jurnal Kajian Pendidikan dan Pembelajaran Vol. 3, No. 1, Th. 2021 
Dian Nurhayati, Ike Sylvia Pengembangan Lembar Kerja Peserta Didik (LKPD) Sosiologi Kelas X SMA Berbasis Discovery Learning

Dataran Tinggi Dieng dengan Model Discovery Learning (DL) untuk Meningkatkan Pemahaman Konsep dan Sikap Peduli Lingkungan Siswa Kelas X SMA di Kabupaten Banjarnegara. Universitas Negeri Yogyakarta.

Istikharah, R. dan Z. S. (2017). Pengembangan Lembar Kegiatan Peserta Didik ( LKPD ) Kelas X SMA / MA Pada Materi Pokok Protista Berbasis Pendekatan Ilmiah. Jurnal Pendidikan Matematika Dan Sains, 12(1), 1-6.

Nasution, M. K. (2017). Penggunaan metode pembelajaran dalam peningkatan hasil belajar siswa. STUDIA DIDAKTIKA: Jurnal Ilmiah Bidang Pendidikan, 11(1), 9-16.

Noor, R. (2017). Penyusunan Lembar Kerja Peserta Didik (Lkpd) Biologi Sma Melalui Inventarisasi Tumbuhan Yang Berpotensi Atau Sebagai Pewarna Alami Di Kota Metro. $\begin{array}{lllll}\text { BIOEDUKASI (Jurnal Pendidikan } & 94 .\end{array}$ https://doi.org/10.24127/bioedukasi.v5i2.788

Nur Inah, E. (2015). Peran Komunikasi Dalam Interaksi Guru dan Siswa. Al-Ta'dib, 8(2), 150167.

Nurhalimah, S. R., Suhartono, S., \& Cahyana, U. (2017). Pengembangan Media Pembelajaran Mobile Learning Berbasis Android pada Materi Sifat Koligatif Larutan. JRPK: Jurnal Riset Pendidikan Kimia, 7(2), 160-167. https://doi.org/10.21009/jrpk.072.10

Nurhasanah, S., \& Sobandi, A. (2016). Minat Belajar Sebagai Determinan Hasil Belajar Siswa. Jurnal Pendidikan Manajemen Perkantoran, 1(1), 128. https://doi.org/10.17509/ jpm.v1i1.3264

Nurliawaty, L., Mujasam, M., Yusuf, I., \& Widyaningsih, S. W. (2017). Lembar Kerja Peserta Didik (Lkpd) Berbasis Problem Solving Polya. JPI (Jurnal Pendidikan Indonesia), 6(1). https://doi.org/10.23887/jpi-undiksha.v6i1.9183

Purwaningrum, J. P. (2016). Mengembangkan Kemampuan Berpikir Kreatif Matematis Melalui Discovery Learning Berbasis Scientific Approach. Refleksi Edukatika, 6(2), 145-157. https://doi.org/10.24176/re.v6i2.613

Puspitasari, A., \& Handziko, R. C. (2018). Pengembangan LKPD mobile learning guided discovery untuk meningkatkan penguasaan kompetensi dasar ekosistem Kurikulum 2013. Jurnal Inovasi Pendidikan IPA.

Sari, A. P. P., \& Lepiyanto, A. (2016). Pengembangan Lembar Kegiatan Peserta Didik (Lkpd) Berbasis Scientific Approach Siswa Sma Kelas X Pada Materi Fungi. BIOEDUKASI (Jurnal Pendidikan Biologi), 7(1), 41-48. https://doi.org/10.24127/bioedukasi.v7i1.489

Setiabudi, A., Susanta, A., \& Maulidiya, D. (2019). Efektifitas Lkpd Dengan Pendekatan Saintifik Untuk Meningkatkan Pemahaman Konsep Matematika Siswa Kelas Viii Smp Negeri 3 Kota Bengkulu. Jurnal Penelitian Pembelajaran Matematika Sekolah (JP2MS), 3, 228-241. https://doi.org/10.33369/jp2ms.3.2.228-241

Syamsu, F. D. (2020). Pengembangan lembar kerja peserta didik berorientasi pembelajaran discovery learning untuk meningkatkan keterampilan berpikir kritis siswa. XI.

Sylvia, I., Anwar, S., \& Khairani, K. (2019). Pengembangan Instrumen Penilaian Autentik Berbasis Pendekatan Authentic Inquiry Learning Pada Mata Pelajaran Sosiologi di Sekolah Menengah Atas. Socius, 6(2), 103-120. https://doi.org/10.24036/scs.v6i2.162

Umbaryanti. (2013). Pentingnya LKPD pada Pendekatan Scientific Pembelajaran Matematika. 217-225. Wijayanti, P. I., \& Hindarto, N. (2012). Eksplorasi Kesulitan Belajar Siswa Pada Pokok Bahasan Cahaya Dan Upaya Peningkatan Hasil Belajar Melalui Pembelajaran Inkuiri Terbimbing. Jurnal Pendidikan Fisika Indonesia, 6(1), 1-1. https://doi.org/10.15294/jpfi.v6i1.1093 